\title{
Asbestos Induces Oxidative Stress and Activation of Nrf2 Signaling in Murine Macrophages: Chemopreventive Role of the Synthetic Lignan Secoisolariciresinol Diglucoside (LGM2605)
}

\author{
Ralph A. Pietrofesa, Anastasia Velalopoulou, Steven M. Albelda \\ and Melpo Christofidou-Solomidou *

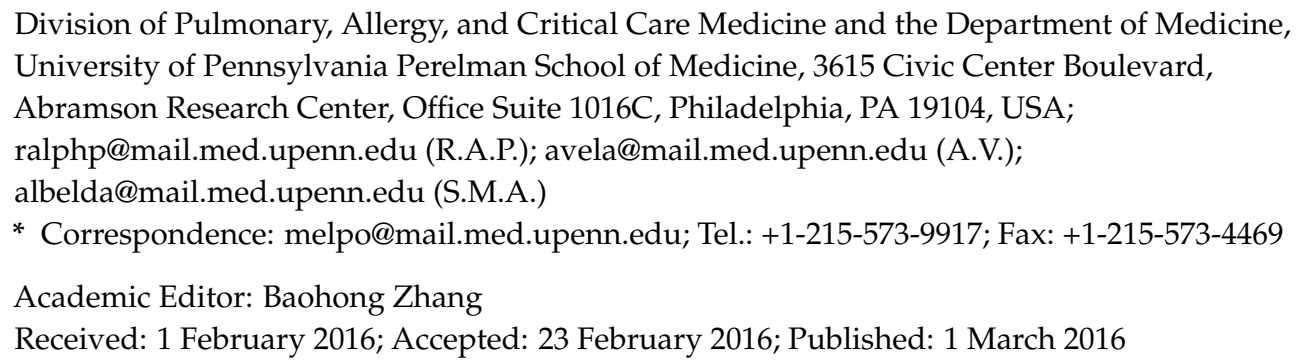

\begin{abstract}
The interaction of asbestos fibers with macrophages generates harmful reactive oxygen species (ROS) and subsequent oxidative cell damage that are key processes linked to malignancy. Secoisolariciresinol diglucoside (SDG) is a non-toxic, flaxseed-derived pluripotent compound that has antioxidant properties and may thus function as a chemopreventive agent for asbestos-induced mesothelioma. We thus evaluated synthetic SDG (LGM2605) in asbestos-exposed, elicited murine peritoneal macrophages as an in vitro model of tissue phagocytic response to the presence of asbestos in the pleural space. Murine peritoneal macrophages (MFs) were exposed to crocidolite asbestos fibers $\left(20 \mu \mathrm{g} / \mathrm{cm}^{2}\right)$ and evaluated at various times post exposure for cytotoxicity, ROS generation, malondialdehyde (MDA), and levels of 8-iso Prostaglandin F2 $\alpha$ (8-isoP). We then evaluated the ability of LGM2605 to mitigate asbestos-induced oxidative stress by administering LGM2605 $(50 \mu \mathrm{M})$ 4-h prior to asbestos exposure. We observed a significant $(p<0.0001)$, time-dependent increase in asbestos-induced cytotoxicity, ROS generation, and the release of MDA and 8-iso Prostaglandin F2 $\alpha$, markers of lipid peroxidation, which increased linearly over time. LGM2605 treatment significantly ( $p$ $<0.0001$ ) reduced asbestos-induced cytotoxicity and ROS generation, while decreasing levels of MDA and 8 -isoP by $71 \%-88 \%$ and $41 \%-73 \%$, respectively. Importantly, exposure to asbestos fibers induced cell protective defenses, such as cellular Nrf2 activation and the expression of phase II antioxidant enzymes, HO-1 and Nqo1 that were further enhanced by LGM2605 treatment. LGM2605 boosted antioxidant defenses, as well as reduced asbestos-induced ROS generation and markers of oxidative stress in murine peritoneal macrophages, supporting its possible use as a chemoprevention agent in the development of asbestos-induced malignant mesothelioma.
\end{abstract}

Keywords: antioxidant; asbestos; LGM2605; lignan; macrophage; mesothelioma; oxidative stress; phase II enzymes; reactive oxygen species; secoisolariciresinol diglucoside

\section{Introduction}

Malignant mesothelioma (MM) is a highly aggressive cancer that arises from the mesothelial cells of the pleura and peritoneum with a median survival of about one year [1-3]. It has now been clearly established in animal models and in patients that asbestos fiber inhalation can lead to neoplastic diseases, such as malignant mesothelioma and lung cancer [4,5], as well as pulmonary fibrosis. Current 
therapies, other than surgery in early disease states, are not curative [6]. MM represents a global health burden, causing approximately 3000 deaths per year in the United States and an additional 5000 deaths per year in Western Europe. Although asbestos use has been restricted in many Western countries, it is still used in many countries around the world and it is estimated that more than two million tons were mined in 2008. Due to the long latency period of MM development (often up to 30-50 years), and the continued exposure to occupational and environmental asbestos worldwide, the future incidence of MM will likely increase.

Persistent asbestos fibers cause the generation of reactive oxygen species (ROS) and oxidative tissue damage that are implicated in the pathogenesis of asbestos-induced cancers $[4,5]$. Inhaled asbestos fibers permeate into the lung, and ultimately to the pleural surface, where they are taken up by tissue phagocytes, primarily macrophages $[7,8]$. It is hypothesized that macrophages exposed to asbestos then undergo frustrated phagocytosis of elongated fibers [9]. This process generates harmful intracellular ROS leading to DNA damage, genomic instability, and ultimately malignant transformation of mesothelial cells [10-14]. A well-tolerated and safe agent with antioxidant properties could thus potentially be used to prevent the development of malignant mesothelioma (MM) in asbestos-exposed populations in a chemopreventive context. According to Greenwald, "the chemoprevention of cancer aims to prevent, arrest, or reverse either the initiation phase of carcinogenesis or the progression of neoplastic cells to cancer" [15]. There is a current unmet need to develop a chemopreventive agent effective against asbestos-induced mesothelioma in high-risk populations. Considering the poor prognosis associated with malignant mesothelioma [16,17], chemopreventive strategies may prove to be beneficial in preventing or delaying MM development.

Previous studies in various models of oxidative stress and pulmonary disease, including acute lung injury from hyperoxia, acid aspiration sepsis [18], ischemia/reperfusion [19,20] and radiationinduced oxidative tissue damage [21] suggested that the flaxseed lignan, secoisolariciresinol diglucoside (SDG) has these requisite antioxidant and ROS scavenging properties [22,23]. We thus hypothesized that SDG or an SDG-rich flaxseed lignan component (FLC)-rich diet might be useful in the chemoprevention of asbestos-induced malignant mesothelioma and have begun a series of studies to test the validity of this idea. In our first study, we evaluated the usefulness of an FLC-supplemented diet in a murine model of acute asbestos-induced peritoneal inflammation and oxidative tissue damage. Three days after intraperitoneal instillation of asbestos into mice, we observed an increase in oxidative and nitrosative stress in the peritoneal fluid, which was significantly attenuated by FLC diet [24]. These findings have led us to conduct more controlled in vitro studies where we can confirm that the effects were due specifically to the purified compound SDG, show that peritoneal macrophages were a key target in this antioxidant effect, and conduct additional mechanistic studies.

To study the chemopreventive usefulness of SDG, in preparation for animal and ultimately human studies, SDG was chemically synthesized (LGM2605) by a proprietary pathway [22]. Similarly to natural SDG extracted from whole grain flaxseed, LGM2605 is a free radical scavenger and antioxidant, with DNA-protective activity [23]. Importantly, in a recent study, LGM2605 showed potent cell-protective and antioxidant properties, while capable of inducing phase II antioxidant, cell-protective enzymes transcriptionally regulated by the nuclear factor (erythroid-derived 2)-like 2 (Nrf2)-antioxidant response element (ARE) signaling pathway [25].

In the present study, we evaluated the usefulness of LGM2605 in preventing asbestos-induced ROS generation and oxidative cell damage in murine peritoneal macrophages. Our objectives were: (1) to characterize the antioxidant response in murine peritoneal macrophages following asbestos exposure; (2) to evaluate the ability of LGM2605 to interfere with asbestos-induced ROS generation and oxidative cell damage in macrophages; and (3) to determine the potential molecular mechanisms through which LGM2605 exerts antioxidant effects following asbestos exposure.

\section{Results}

To determine the usefulness of synthetic SDG (LGM2605) in preventing asbestos-induced ROS generation and oxidative cell damage, we utilized elicited murine peritoneal macrophages as a model of tissue phagocytic response to the presence of asbestos in the pleural space. We determined the 
kinetics of asbestos-induced ROS generation, cytotoxicity, oxidative cell damage, Nrf2 activation, and associated changes in relevant Nrf2-regulated phase II antioxidant enzymes at various times post asbestos exposure.

\subsection{Determination of Dose-Response Following Asbestos Exposure and LGM2605}

We first empirically determined the optimal level of asbestos exposure (Figure 1a) and LGM2605 dosing (Figure $1 b$ ) in murine elicited peritoneal macrophages. We evaluated asbestos-induced ROS generation following cell exposure to various concentrations of crocidolite asbestos fibers $(0,1,5,10$, and $20 \mu \mathrm{g} / \mathrm{cm}^{2}$ ). Macrophage exposure to crocidolite asbestos fibers led to significant ROS generation in a dose-dependent manner (Figure 1a). The $20 \mu \mathrm{g} / \mathrm{cm}^{2}$ dose of asbestos induced a robust 2.3-fold increase in ROS and was thus selected as the dose for all experiments performed. Additionally, we tested the antioxidant properties of LGM2605 at various concentrations $(0,10,25,50$, and $100 \mu \mathrm{M})$ and determined a significant reduction in ROS following asbestos exposure in a dose-responsive fashion (Figure 1b). Treatment with $50 \mu \mathrm{M}$ LGM2605 led to a significant $43 \%$ reduction in ROS relative to untreated macrophages and was selected as the optimal treatment dose for evaluating the preventive properties of LGM2605 in attenuating the deleterious effects of asbestos exposure. Importantly, the dose of LGM2605 $(\mu \mathrm{M})$ used in the in vitro studies described here is comparable to tissue levels achieved following oral administration of a physiologically relevant dose in mice.
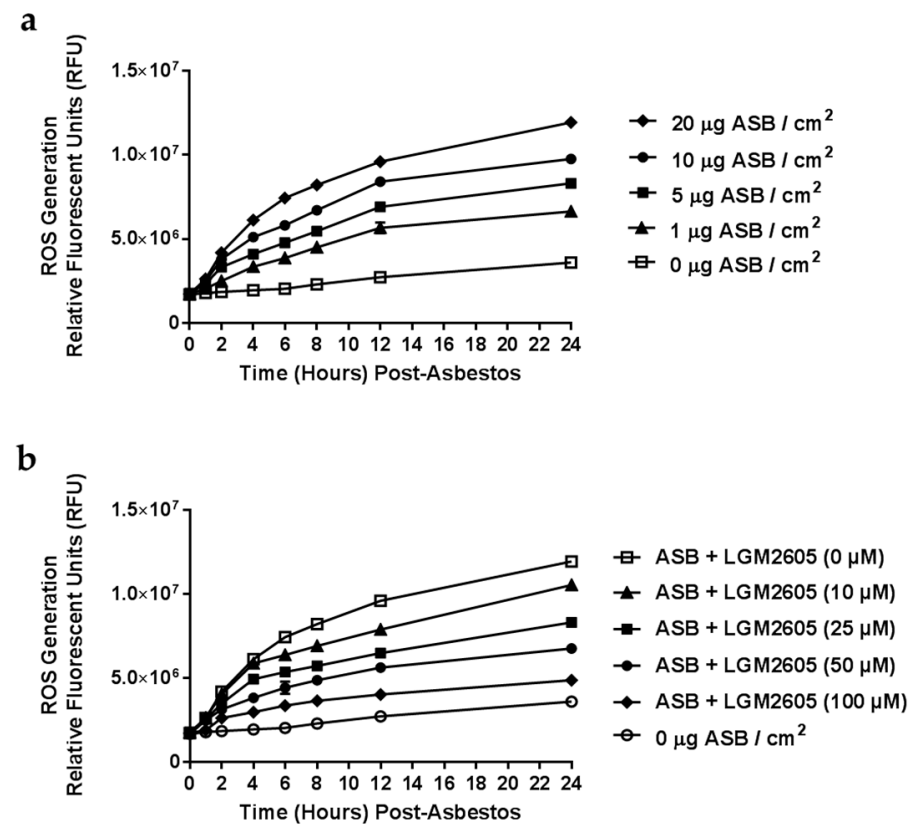

Figure 1. Determination of Dose-Response Following Asbestos Exposure and LGM2605. (a) Elicited murine peritoneal macrophages were plated in a 96-well plate $\left(2 \times 10^{4}\right.$ cells /well $)$ and exposed to various concentrations of sterile, standard UICC (Union Internationale Contre le Cancer) crocidolite (SPI Supplies, West Chester, PA, USA) asbestos fibers $\left(0,1,5,10\right.$, and $\left.20 \mu \mathrm{g} / \mathrm{cm}^{2}\right)$ to first assess the dose-dependent increase in asbestos-induced ROS generation; (b) Various concentrations (0, 10, 25, 50 , and $100 \mu \mathrm{M}$ ) of synthetic SDG (LGM2605) were administered 4-h prior to exposure to crocidolite asbestos $\left(20 \mu \mathrm{g} / \mathrm{cm}^{2}\right)$. Culture medium was evaluated for ROS generation using the cell-permeant fluorescent probe $2^{\prime}, 7^{\prime}$-dichlorodihydrofluorescein diacetate (H2DCFDA).

\subsection{LGM2605 Reduces Asbestos-Induced ROS Generation and Cytotoxicity}

We next utilized elicited murine peritoneal macrophages to study the effect of LGM2605 treatment on asbestos-induced cellular ROS generation, oxidative stress, and induction of Nrf2 signaling. LGM2605 treatment $(50 \mu \mathrm{M})$ was initiated 4-h prior to exposure to crocidolite asbestos fibers $\left(20 \mu \mathrm{g} / \mathrm{cm}^{2}\right)$ and cell culture medium and macrophages were collected at $0,1,2,4,6,8,12$, and 24-h post asbestos exposure (Figure 2). 


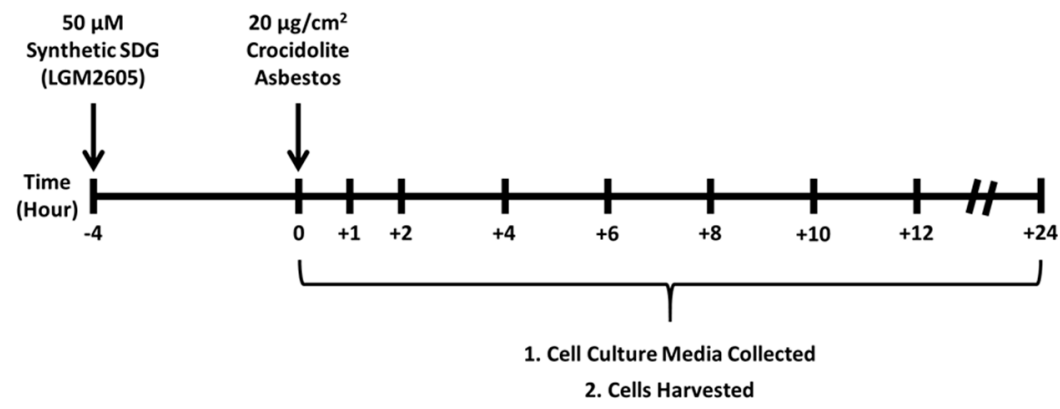

Figure 2. Experimental plan of asbestos exposure, LGM2605 Treatment, and Harvest Time Points. Murine peritoneal macrophages were exposed to $50 \mu \mathrm{M}$ synthetic SDG (LGM2605) 4-h prior to exposure to sterile UICC crocidolite (SPI Supplies) asbestos fibers $\left(20 \mu \mathrm{g} / \mathrm{cm}^{2}\right)$. Culture medium and cells were harvested at $0,1,2,4,6,8,12$, and 24-h post asbestos exposure. Culture medium was evaluated for $\mathrm{H}_{2} \mathrm{O}_{2}$ content, lactate dehydrogenase (LDH) release, levels of MDA and 8-iso Prostaglandin F2a, while cells were harvested for gene and protein expression analysis.

We determined the kinetics of ROS generation and cytotoxicity following exposure to $20 \mu \mathrm{g} / \mathrm{cm}^{2}$ crocidolite asbestos by measuring levels of $\mathrm{H}_{2} \mathrm{O}_{2}$ released into the culture medium as measured by Amplex Red (Figure 3a). Minimal $\mathrm{H}_{2} \mathrm{O}_{2}$ was released by control (non-asbestos-exposed) cells or by cells treated with LMG2605-alone. In contrast, $\mathrm{H}_{2} \mathrm{O}_{2}$ levels rapidly increased within $30 \mathrm{~min}$ post asbestos exposure (from $0.24 \pm 0.03$ to $1.83 \pm 0.06 \mu \mathrm{M} \mathrm{H}_{2} \mathrm{O}_{2}$ ) and remained elevated after 12-h. Pretreatment with LGM2605 at a dose of $50 \mu \mathrm{M}$ significantly $(p<0.0001)$ reduced levels of $\mathrm{H}_{2} \mathrm{O}_{2}$ by $54 \%-80 \%$ (Figure 3a). We conducted similar studies to assess asbestos-induced cytotoxicity by measuring LDH release (Figure 3b). Again, minimal LDH was released by control (non-asbestos-exposed) cells or by cells treated with LMG2605-alone. However, starting at 4-h after asbestos exposure (following the initial increase in asbestos-induced $\mathrm{H}_{2} \mathrm{O}_{2}$ release), we detected a significant $(p<0.0001)$ cytotoxic effect. Pretreatment with LGM2605 at a dose of $50 \mu \mathrm{M}$ significantly $(p<0.0001)$ reduced LDH release (Figure 3b). Levels of $\mathrm{H}_{2} \mathrm{O}_{2}$ and $\mathrm{LDH}$ released into the cell culture medium were not determined 24-h post asbestos exposure, since the release of $\mathrm{H}_{2} \mathrm{O}_{2}$ and $\mathrm{LDH}$ into the cell culture medium had reached a plateau by 10 to 12 -h post asbestos exposure.
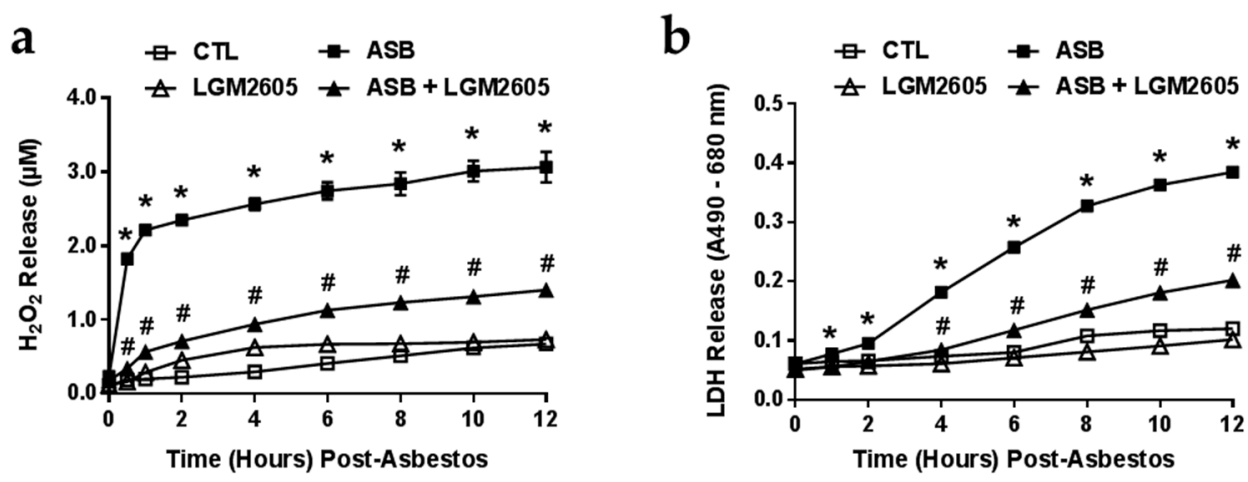

Figure 3. ROS Production and Cytotoxicity Following Asbestos Exposure. Elicited murine peritoneal macrophages were plated in a 6-well plate $\left(2 \times 10^{6}\right.$ cells/well $)$ and exposed to $50 \mu \mathrm{M}$ synthetic SDG (LGM2605) 4-h prior to exposure to sterile UICC crocidolite (SPI Supplies) asbestos fibers $\left(20 \mu \mathrm{g} / \mathrm{cm}^{2}\right)$. (a) Murine peritoneal macrophage release of $\mathrm{H}_{2} \mathrm{O}_{2}(\mathbf{b})$ and lactate dehydrogenase (LDH) was determined at $0,1,2,4,6,8,10$ and 12-h post asbestos exposure. Samples were run undiluted in triplicate and data are presented as mean \pm the standard error of the mean (SEM). * indicates a statistically significant difference $(p<0.05)$ between asbestos-only (ASB) and control (CTL) treated cells; \# indicates a statistically significant difference $(p<0.05)$ between ASB and asbestos + LGM2605 (ASB + LGM2605) treated cells. 


\subsection{The Synthetic SDG (LGM2605) Reduces Asbestos-Induced Lipid Peroxidation and Oxidative Cell Damage}

Minimal levels of MDA were detected in control (non-asbestos-exposed) cells or by cells treated with LMG2605-alone (Figure 4a). Levels of MDA were significantly $(p<0.0001)$ elevated after 30-min of asbestos exposure and continued to accumulate in the cell culture medium (33.16 $\pm 0.58 \mu \mathrm{M}$ at $24-h$ post asbestos). LGM2605 treatment significantly $(p<0.0001)$ reduced levels of MDA by $71 \%-88 \%$ $(9.70 \pm 0.54 \mu \mathrm{M}$ at 24 -h post asbestos) (Figure $4 \mathrm{a}$ ).
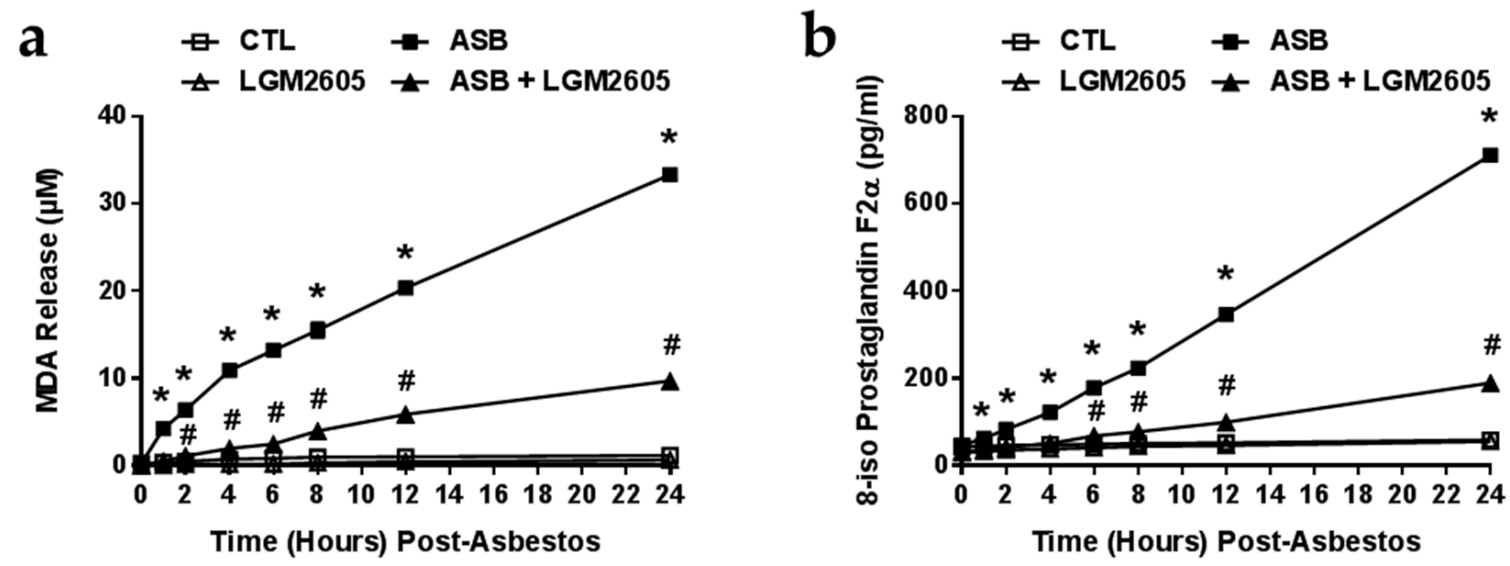

Figure 4. LGM2605 Prevents Oxidative Cell Damage and the Release of MDA and 8-IsoP. Elicited murine peritoneal macrophages were plated in a 6-well plate $\left(2 \times 10^{6}\right.$ cells / well $)$ and exposed to $50 \mu \mathrm{M}$ synthetic SDG (LGM2605) 4-h prior to exposure to sterile UICC crocidolite (SPI Supplies) asbestos fibers $\left(20 \mu \mathrm{g} / \mathrm{cm}^{2}\right)$. The levels of (a) MDA and (b) 8-iso Prostaglandin F2a were determined in the cell culture medium at $0,1,2,4,6,8,12$ and 24-h post asbestos exposure. Data are presented as mean \pm SEM. * indicates a statistically significant difference $(p<0.05)$ between ASB and CTL treated cells; \# indicates a statistically significant difference $(p<0.05)$ between ASB and ASB + LGM2605 treated cells.

We also evaluated levels of 8-iso Prostaglandin F2a in the cell culture medium as a marker of oxidative stress and cell damage following asbestos exposure (Figure 4b). Minimal levels of 8-isoP were released by control (non-asbestos-exposed) cells or by cells treated with LMG2605-alone. Asbestos exposure led to a significant increase in the concentration of 8 -isoPs $(710.87 \pm 5.55 \mathrm{pg} / \mathrm{mL}$ at $24-\mathrm{h}$ post asbestos) that was significantly blunted by the administration of LGM2605 $(189.89 \pm 2.58 \mathrm{pg} / \mathrm{mL})$ (Figure 4b).

\subsection{Exposure to Crocidolite Asbestos Fibers Induces Phase II Antioxidant Enzyme Expression in Murine Macrophages}

To investigate the underlying mechanisms behind the decrease in lipid peroxidation and oxidative stress by LGM2605 treatment, we evaluated protein and gene expression changes in heme oxygenase- 1 (HO-1) and NADPH: quinone oxidoreductase-1 (Nqo1) (Figure 5), important enzymes stimulated by the Nrf2-ARE pathway critical in the detoxification of free radicals and reactive oxygen species. We first determined the kinetics of asbestos-induced protein expression of HO-1 and Nqo1. Starting at a very low baseline, asbestos exposure induced the expression of HO-1 (Figure 5a,b) significantly $(p<0.05)$ above baseline levels as early as 4 -h post exposure. Levels of Nqo1 increased sharply after $12 \mathrm{~h}$ (Figure $5 \mathrm{a}, \mathrm{c}$ ). We therefore evaluated the effect of LGM2605 treatment on antioxidant enzyme gene expression at 8 and 24 -h post asbestos exposure. 
a
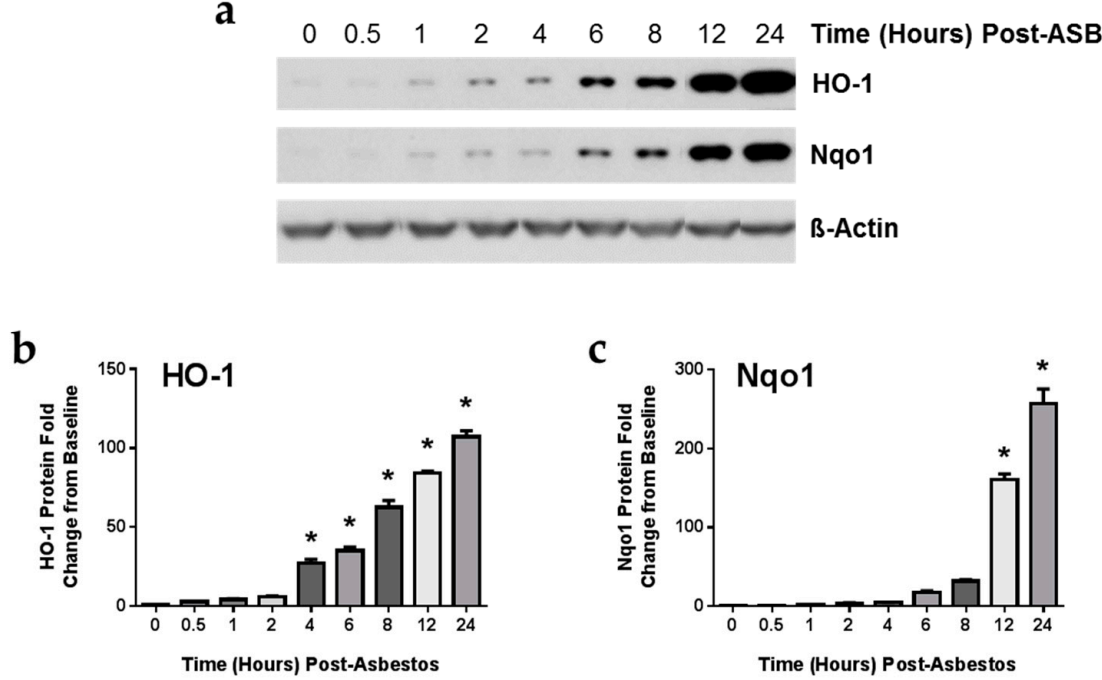

Figure 5. Asbestos Exposure Induces the Expression of Phase II Antioxidant Enzymes. Elicited murine peritoneal macrophages were harvested after 0, 0.5, 1, 2, 4, 5, 8, 12, and 24-h of asbestos exposure and evaluated by (a) Western blotting for HO-1 and Nqo1. Densitometric analysis of band intensity for (b) HO-1 and (c) Nqo1 was normalized to $\beta$-actin and values are expressed as fold change from CTL at time 0 . Data are presented as mean \pm SEM. ${ }^{*}$ indicates a statistically significant $(p<0.05)$ increase in HO-1 and Nqo1 protein levels above baseline values at time 0 .

\subsection{LGM2605 Enhances Asbestos-Induced Activatation Nrf2 Signaling and Gene Expression of Phase II Enzymes}

After evaluating the kinetics of antioxidant enzyme expression following asbestos exposure, we determined the effects of asbestos exposure on Nrf2 signaling. Cellular oxidative stress leads to the activation of the Nrf2-ARE pathway, which transcriptionally regulates many antioxidant and cytoprotective genes responsible for cellular homeostasis. We, thus, determined Nrf2 activation following asbestos exposure and assessed gene expression changes in HO-1 and NQO1.

We first determined levels of Nrf2 in macrophage nuclear extracts, an indicator of active Nrf2 that has exited the cytosol after being cleaved from Kelch-like ECH-associated protein 1 (Keap1), and determined the kinetics of Nrf2 nuclear accumulation following asbestos exposure (Figure 6a). Nuclear Nrf2 was low at baseline and did not significantly change over time. However, pretreatment with $50 \mu$ M LGM2605 led to significant $(p<0.0001)$ activation of Nrf2 signaling at baseline prior to asbestos exposure that remained elevated through the 12-h of observation (elevated 2.81-fold from control, non-asbestos exposed macrophages). Following asbestos exposure, we observed significantly $(p<0.0001)$ increased levels of nuclear Nrf2, with the highest concentration occurring after 2 and 12-h post exposure. Levels of Nrf2 from nuclear extracts of macrophages treated with LGM2605 and asbestos were significantly $(p<0.0001)$ elevated above asbestos-only exposure.

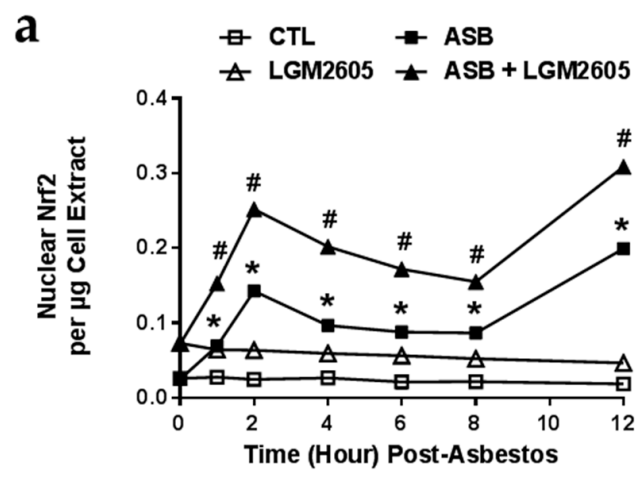

Figure 6. Cont. 
b

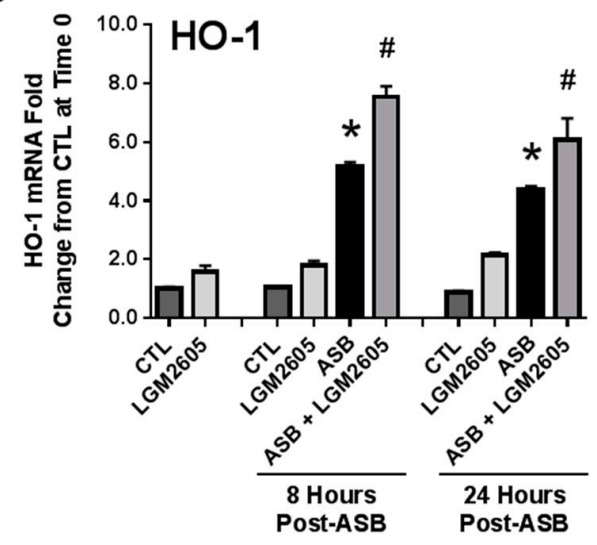

C

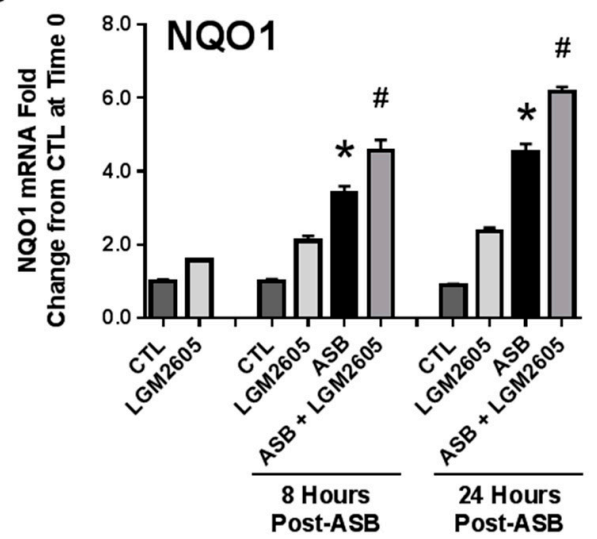

Figure 6. LGM2605 Boosts Nrf2 Activation and the Expression of Antioxidant Enzymes in Elicited Murine Peritoneal Macrophages. (a) Levels of active, nuclear Nrf2 were determined at 0, 1, 2, 4, 6, 8, and 12-h post asbestos exposure; Macrophage mRNA expression of (b) HO-1 and (c) NQO1 was determined at 0,8 , and 24 -h post asbestos exposure using qPCR. Levels of target gene mRNA were normalized to $\beta$-actin RNA and values are expressed as fold change from CTL. Data are presented as mean \pm SEM. * indicates a statistically significant difference $(p<0.05)$ between ASB and CTL treated cells; " indicates a statistically significant difference $(p<0.05)$ between ASB and ASB + LGM2605 treated cells.

Upon determination of HO-1 and NQO1 gene expression, treatment with LGM2605-alone led to significant $(p<0.0001)$ elevations in mRNA levels $(1.58 \pm 0.21$ and $1.58 \pm 0.02$ fold change from control, respectively) at all time points evaluated (Figure 6b,c). Importantly, although mRNA levels of HO-1 and NQO1 were significantly elevated above control after 8 and 24-h of asbestos exposure, treatment with LGM2605 further boosted antioxidant gene expression above asbestos-only exposure (Figure $6 \mathrm{~b}, \mathrm{c}$ ) by an additional $28 \%-31 \%$ and $25 \%-26 \%$, respectively.

\subsection{Induction of Cellular Antioxidant Enzymes by Asbestos and Further Activation by LGM2605}

When we evaluated protein levels of these Nrf2-inducible antioxidant enzymes, we observed increased protein expression in macrophages treated with asbestos and LGM2605 at both 8 and 24-h post asbestos exposure. Importantly, treatment of macrophages with LGM2605-alone led to a robust increase in the expression of both $\mathrm{HO}-1$ and Nqo1 prior to asbestos exposure $(2.45 \pm 0.11$ and $9.94 \pm 0.49$ fold change from control, respectively). Although protein levels of HO-1 (Figure 7a,b) and Nqo1 (Figure 7a,c) were significantly elevated above control after 8 and 24-h of exposure, macrophages treated with LGM2605 displayed a further increase in both antioxidant enzymes by 39\%-40\% and $60 \%-79 \%$, respectively.

a

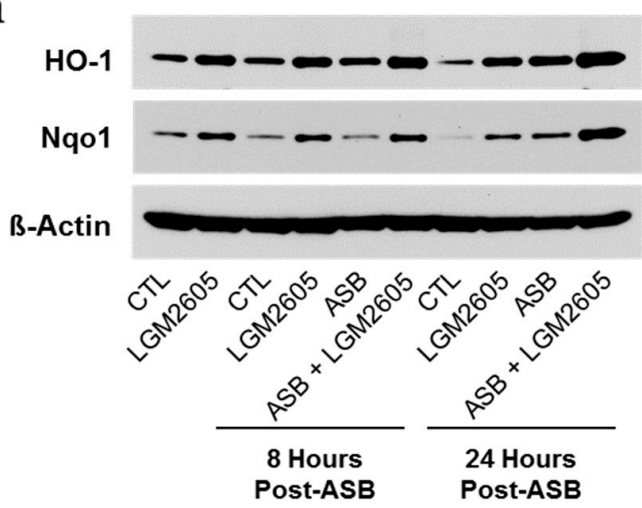

Figure 7. Cont. 
b

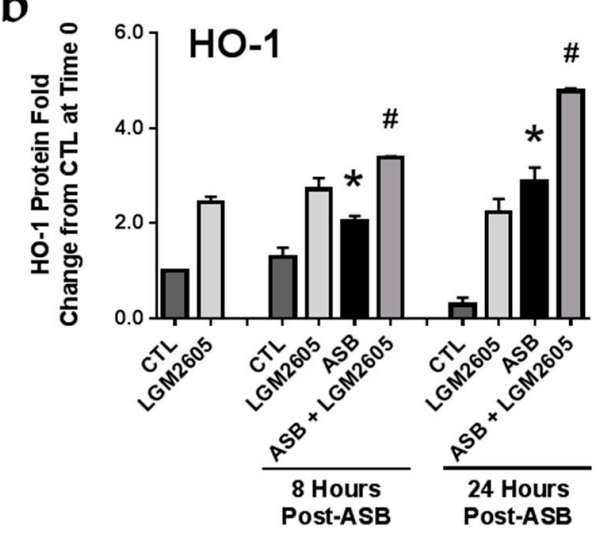

C

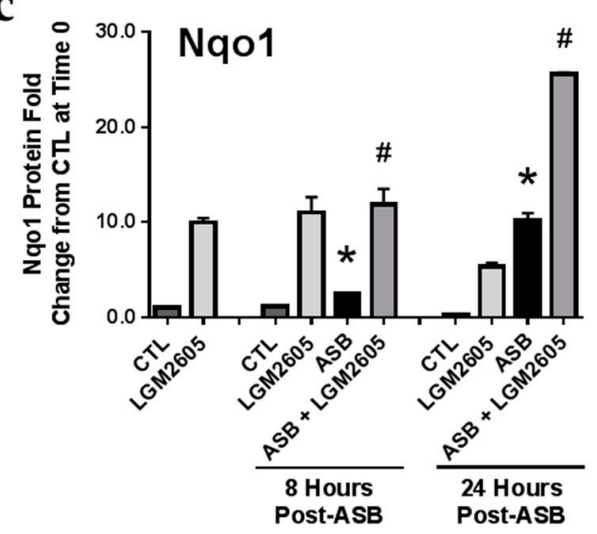

Figure 7. The Synthetic Lignan SDG (LGM2605) Enhances the Expression of Nrf2-Regulated Antioxidant Enzymes in Elicited Murine Peritoneal Macrophages. Levels of antioxidant enzymes were determined by (a) Western blotting for HO-1 and Nqo1; Densitometric analysis of band intensity for (b) HO-1 and (c) Nqo1 was normalized to $\beta$-actin and values are expressed as fold change from CTL at time 0 . Data are presented as mean \pm SEM. ${ }^{*}$ indicates a statistically significant difference $(p<0.05)$ between ASB and CTL treated cells; " indicates a statistically significant difference $(p<0.05)$ between ASB and ASB + LGM2605 treated cells.

\section{Discussion}

Our current findings highlight the dual role of LGM2605 in scavenging ROS and inducing phase II antioxidant enzymes in an in vitro model of asbestos exposure utilizing murine peritoneal macrophages as an in vitro model of tissue phagocytic response to the presence of asbestos in the pleural space. First, we observed the ability of LGM2605 to blunt asbestos-induced ROS generation and cytotoxicity. Lipid peroxidation plays a major role in mediating oxidative damage in tissues, is a qualitative indicator of oxidative stress within tissues and cells, and can be measured by determining the amount of malondialdehyde (MDA), a product of lipid peroxidation [21,26]. We determined decreased levels of MDA and 8-isoP with LGM2605 treatment, indicative of decreased asbestos-induced oxidative stress. Importantly, while asbestos exposure activates Nrf2 signaling and the expression of phase II antioxidant enzymes, LGM2605 further enhances levels of key antioxidant enzymes involved in the detoxification of reactive oxygen species. Of note, LGM2605 boosted antioxidant defenses at baseline prior to asbestos exposure and were further augmented by the asbestos challenge. Our findings support the usefulness of LGM2605 as a potential chemopreventive agent in reducing the early cytotoxicity and oxidative cell damage that occurs following asbestos exposure.

We have previously evaluated the ability of a flaxseed lignan diet, enriched in the natural form of biphenolic SDG, to prevent acute asbestos-induced inflammation and oxidative/nitrosative stress in a murine model of peritoneal asbestos exposure [24]. Specifically, mice fed an FLC diet, enriched in SDG, displayed a $74.6 \%$ reduction in levels of the MDA in the peritoneal lavage fluid (PLF) at three days post intraperitoneal asbestos exposure. In accordance with our current findings, peritoneal white blood cells from mice fed an SDG-rich FLC diet had significantly increased mRNA levels of HO-1, NQO1, and glutathione S-transferase mu 1 (GSTM1) compared to CTL-fed mice. Combined, our findings highlight the usefulness of SDG (LGM2605) in the detoxification of free radicals and ROS following asbestos exposure. Importantly, our current findings point towards the role of LGM2605 as an activator of Nrf2 signaling and an inducer of phase II antioxidant enzymes. In addition, we have confirmed that the antioxidant effects from feeding an SDG-rich FLC diet were due specifically to the purified compound SDG (LGM2605) and have shown that peritoneal macrophages are a key target in this antioxidant effect.

Although the idea of chemoprevention sounds simple, it has been very difficult to find effective cancer chemopreventive agents. First, the mechanisms by which carcinogens induce cancer usually 
involve multiple molecular pathways, making efficacy challenging and requiring an agent with multiple biological activities. Second, since the agent will be used to prevent a small number of tumors in a large population of healthy, but at-risk individuals, it must be extraordinarily non-toxic, well-tolerated, and affordable. Dietary chemoprevention strategies for induction of Nrf2/ARE activation have been attempted in multiple studies [27] using dietary natural or synthetic agents such as isothiocyanates or dithiolethiones [28,29]. The cancer chemopreventive actions of Oltipraz (OLZ), a member of a class of 1,2-dithiolethiones, primarily associated with the induction of phase II enzymes was shown in studies to decrease tumor burden in mice in an Nrf2-dependent manner. OLZ, like most other known phase II inducers, was associated with serious and deleterious adverse effects in human clinical trials, including hepatotoxicity [30]. Agents such as OLZ are actually oxidants, themselves, that stimulate Nrf2 by placing the cell under mild oxidant stress [31]. Specifically, dithiolethiones were recently found to generate superoxide, thus providing a mechanistic explanation for their ability to induce Nrf2-dependent phase II enzymes [32]. Unfortunately, these agents have also proven to be rather toxic [33]. Flaxseed lignans in contrast, directly detoxify ROS, specifically the hydroxyl radical $(\bullet \mathrm{OH})$, which is the most reactive of all reactive oxygen species [34,35]. A particularly exciting aspect of our findings is that flaxseed or the flaxseed lignan SDG and its synthetic counterpart, LGM2605, all activate the Nrf2-ARE system, thus amplifying its antioxidant potency, but in a uniquely non-toxic fashion. Safe, non-toxic use of flaxseed or its lignan components was shown not only by our group [19,25,36], but has been confirmed by others as well [37-39].

SDG, an antioxidant isolated from flaxseed, is metabolized by intestinal bacteria to enterodiol (ED), and enterolactone (EL) which are bioactive. However, SDG also has strong direct antioxidant properties in vitro without the need for metabolic activation [21]. The antioxidant activities of these three lignans (SDG, EL and ED) were shown by their ability to inhibit linoleic acid lipid peroxidation, indicating direct hydroxyl radical scavenging activity [35,40]. Since oxidant stress is implicated in the etiology of cancer, the therapeutic or preventive use of dietary flaxseed or flaxseed-derived lignans has been considered in some tumors. Lignans were shown to reduce chemically-induced mammary and colon tumorigenesis in rats [41-43] and experimental metastasis of melanoma cells in mice [44]. The flaxseed lignan SDG is now emerging as a potential anticarcinogenic agent and found to modulate growth factor-mediated cell signaling, cell cycle gene expression and apoptosis [45-48].

Flaxseed or flaxseed lignans have never been evaluated in lung diseases until our group pioneered its use in a series of studies including hyperoxia, acid aspiration, and lipopolysaccharide- induced acute lung injury [18]. We recently extended the findings of flaxseed protection in models of warm lung ischemia/reperfusion injury [19] and pneumonitis, resulting from thoracic radiation [21]. In the course of our studies, we made the important observation that flaxseed, specifically the bioactive lignan component enriched in SDG, had the ability to upregulate phase II enzymes and other antioxidant enzymes in cell culture and in whole animals through activation of the transcription factor Nrf2 [25,49]. The ability of flaxseed to activate Nrf2, coupled with its direct antioxidant activity generated our key hypothesis, that flaxseed could function as a safe, non-toxic chemopreventive agent for asbestos-induced mesothelioma.

Asbestos fibers have been shown to participate in redox reactions to generate reactive oxygen species by multiple mechanisms, including hydroxyl radicals generated either through a redox reaction or by catalyzing a Fenton-like reaction in exposed cells [50]. Asbestos fiber internalization generates a significant increase in intracellular ROS and there is considerable evidence that asbestos-initiated chronic oxidative stress contributes to carcinogenesis and fibrosis by promoting oxidative DNA damage and regulating redox signaling pathways in exposed cells [51].

We report the ability of LGM2605 to both scavenge free radicals and detoxify ROS through direct and indirect molecular effects. We have previously reported the direct free radical scavenging ability of SDG in a murine endothelial cell model of gamma radiation-induced ROS [21] and therefore studied this potential mechanism in our system. LGM2605 likely acted as a direct free radical scavenger and antioxidant in a dose-responsive manner. In addition to the direct free radical scavenging ability of 
LGM2605, we have shown that flaxseed, and it bioactive lignan component, can activate Nrf2 in normal cells and tissues $[18,19,21,49,52]$. Nrf2 is a master transcriptional regulator of carcinogen detoxifying and antioxidant enzymes (such as $\mathrm{HO} 1$ and Nqo1) and plays a major role in tissue protection. These findings are in agreement with those of Velalopoulou et al. [25], where LGM2605 protected normal lung cells from radiation-induced DNA damage through direct free radical scavenging and boosting of endogenous antioxidant enzyme gene expression.

In a recent review Neri et al. [5] summarized the status of chemoprevention of asbestos-linked cancer. Almost all of the 46 citations focused on aspects of a series of large clinical trials started between 1985 and 1991, using one agent: $\beta$-carotene. This was based on observational studies showing that people eating more fruits and vegetables, which are rich in $\beta$-carotene, had lower rates of lung cancer. They identified three large published trials: the CARET trial (which had 4000 asbestos-exposed workers), the Tyler Asbestos Workers Program (755 exposed persons), and the Wittenoom Crocidolite Industry Program ( 1000 participants). Unfortunately, the results in all of these trials showed either an increased incidence of cancer or no clear efficacy. No new trials have been started in the last 20 years. In their review, Neri et al. [5] only found three publications testing other agents in in vitro studies looking at an inhibitor of cyclooxygenase-2 (COX-2), selenium, and butyrate. Two recent additional studies evaluated the effects of a COX-2 inhibitor and of Vitamin A, Vitamin E, and selenium in a mouse model of asbestos-induced MM [53,54]. These studies used a new transgenic mouse model of mesothelioma in which the SV40 large T-antigen was driven by a mesothelin promoter (MexTag mice) [53]. These mice do not spontaneously develop MM, but if injected with asbestos intraperitoneally will all reproducibly develop mesothelioma within 40 weeks. Of note, none of the agents tested reduced the incidence of asbestos-induced MM.

Despite past failures [5] and considerable challenges in identifying a useful chemopreventive agent, we believe the strategy of chemoprevention for asbestos-induced MM holds special promise and should be actively pursued because: (1) we have the ability to identify a clear at-risk population (asbestos-exposed individuals); (2) there is a long latency period where interventions will have time to work; (3) there is no effective therapy or proven screening approach; (4) good mouse models exist which closely mimic the human situation where asbestos causes MM; (5) there is a new and growing understanding of the mechanisms by which asbestos induces MM; (6) some interesting new biomarkers are emerging, i.e., HMGB1 [55], mesothelin [56], and fibulin-3 [57] that could provide key intermediate endpoints, and (7) we have identified what we think is an ideal non-toxic, yet potentially efficacious, chemopreventive agent (LGM2605) that inhibits both asbestos-induced inflammation and ROS/reactive nitrogen species (RNS) generation.

\section{Materials and Methods}

\subsection{Harvesting of Murine Peritoneal Macrophages}

Murine peritoneal macrophages (MF) were harvested from the peritoneum following elicitation using thioglycollate broth. Mice were used at 13 weeks of age under animal protocols approved by the Institutional Animal Care and Use Committee (IACUC) of the University of Pennsylvania, (Philadelphia, PA, USA). Animals were housed in conventional cages under standardized conditions with controlled temperature and humidity, and a 12-12-h day-night light cycle. Animals had free access to water and mouse chow. Mice were injected, via intraperitoneal (IP) injection, with $1 \mathrm{~mL}$ of a $3 \%$ solution of thioglycollate broth in $0.5 \mathrm{~mL}$ phosphate-buffered saline (PBS). Three days following thioglycollate exposure, mice were euthanized using an overdose of ketamine $(160 \mathrm{mg} / \mathrm{kg})$ and xylazine $(25 \mathrm{mg} / \mathrm{kg})$. Peritoneal lavage (PL) was then performed through a 20-gauge angiocatheter (BD Pharmingen, San Diego, CA, USA), with the intraperitoneal instillation of $3 \mathrm{~mL}$ Hanks balanced salt solution (HBSS; $\mathrm{Ca}^{2+}$ and $\mathrm{Mg}^{2+}$ free). An aliquot of peritoneal lavage fluid (PLF) was immediately separated to measure total white blood cell (WBC) counts (cells/ml PLF) using a Coulter Cell and Particle Counter (Beckman Coulter, Miami, FL, USA). Murine peritoneal macrophages were plated in 
$1 \mathrm{~mL}$ of cell culture medium phenol-free RPMI supplemented with $1 \%$ FBS, penicillin (100 units $/ \mathrm{mL}$ ) and streptomycin $(100 \mu \mathrm{g} / \mathrm{mL})$, and L-Glutamine $(2 \mathrm{~mm})$ in a 6-well plate $\left(2 \times 10^{6}\right.$ cells $/$ well $)$ and allowed to adhere to the bottom of the wells. Elicited peritoneal macrophages were used to determine the effects of LGM2605 in preventing asbestos-induced cytotoxicity, generation of reactive oxygen species (ROS), oxidative cell damage, and cellular antioxidant response.

\subsection{Crocidolite Asbestos Exposure}

Elicited peritoneal macrophages were exposed to sterile UICC (Union Internationale Contre le Cancer) crocidolite $\left(\mathrm{Na}_{2} \mathrm{O} \cdot \mathrm{Fe}_{2} \mathrm{O}_{3} \cdot 8 \mathrm{SiO}_{2} \cdot \mathrm{H}_{2} \mathrm{O}\right)$ asbestos fibers (SPI Supplies, West Chester, PA, USA) that were baked overnight, resuspended in $1 \mathrm{X}$ PBS at a stock concentration of $800 \mu \mathrm{g} / \mathrm{mL}$ and sonicated for $30 \mathrm{~min}$. The solution of asbestos fibers was exposed to ultraviolet light prior to use in cell culture experiments. Initial experiments were conducted using various concentrations of asbestos fibers $(0,1$, 5,10 , and $20 \mu \mathrm{g} / \mathrm{cm}^{2}$ ) to assess the dose-dependent effect of asbestos exposure (see Figure 1a). In all subsequent experiments, murine peritoneal macrophages were exposed to crocidolite asbestos fibers at a concentration of $20 \mu \mathrm{g} / \mathrm{cm}^{2}$.

\subsection{Synthetic SDG (LGM2605) Exposure}

Synthesis of secoisolariciresinol diglucoside has been previously described [22]. Briefly, secoisolariciresinol diglucosides $(S, S)-S D G$ (the major isomer in whole grain flaxseed) and $(R, R)-$ SDG (the minor isomer in whole grain flaxseed) were synthesized from vanillin via secoisolariciresinol and a glucosyl donor (perbenzoyl-protected trichloroacetimidate under the influence of TMSOTf) through a concise route that involved chromatographic separation of diastereomeric diglucoside derivatives. Synthetic SDG (LGM2605) was reconstituted to a stock concentration of $10 \mathrm{mM}$ and cells were exposed to $50 \mu \mathrm{M}$ SDG 4-h prior to asbestos exposure (see Figure 2). Initial experiments were conducted using various concentrations of LGM2605 $(0,10,25,50$, and $100 \mu \mathrm{M})$ to assess the dose-dependent effect of LGM2605 treatment (see Figure 1b). In all subsequent experiments, murine peritoneal macrophages were treated with $50 \mu \mathrm{M}$ LGM2605 4-h prior to asbestos exposure.

\subsection{Determination of Intracellular Asbestos-Induced ROS Generation}

Levels of intracellular ROS were determined using the cell-permeant fluorescent probe $2^{\prime}, 7^{\prime}$-dichlorodihydrofluorescein diacetate (H2DCFDA) (Molecular Probes ${ }^{\circledR}$, ThermoFisher Scientific, Waltham, MA, USA). Upon cleavage of the acetate groups by intracellular esterases and oxidation, the nonfluorescent H2DCFDA is converted to the highly fluorescent $2^{\prime}, 7^{\prime}$-dichlorofluorescein (DCF). Elicited murine peritoneal macrophages were plated in a 96-well plate $\left(2 \times 10^{4}\right.$ cells /well $)$ and exposed to various concentrations of sterile UICC crocidolite (SPI Supplies) asbestos fibers $(0,1,5,10$, and $\left.20 \mu \mathrm{g} / \mathrm{cm}^{2}\right)$ and LGM2605 (0, 10, 25, 50, and $\left.100 \mu \mathrm{M}\right)$. The fluorescence intensity was then measured on a SpectraMax i3x Multi-Mode microplate reader (Molecular Devices, Sunnyvale, CA, USA) using an excitation wavelength in the range of $492-495 \mathrm{~nm}$ and a fluorescence emission detection at 517-527 nm.

\subsection{Quantification of $\mathrm{H}_{2} \mathrm{O}_{2}$ Release from Peritoneal Macrophages Following Asbestos Exposure}

As a measure of asbestos-induced ROS generation, we determined extracellular levels of $\mathrm{H}_{2} \mathrm{O}_{2}$ following asbestos exposure at $0,0.5,1,2,4,6,8,10$, and 12-h post-exposure. Elicited murine peritoneal macrophages were plated in a 6-well plate $\left(2 \times 10^{6}\right.$ cells/well $)$ and exposed to $50 \mu \mathrm{M}$ synthetic SDG (LGM2605) 4-h prior to exposure to sterile UICC crocidolite (SPI Supplies) asbestos fibers $\left(20 \mu \mathrm{g} / \mathrm{cm}^{2}\right)$. The release of $\mathrm{H}_{2} \mathrm{O}_{2}$ by murine peritoneal macrophages was quantified using the Amplex Red enzyme assay (Molecular Probes ${ }^{\circledR}$, ThermoFisher Scientific, Waltham, MA, USA), which utilizes horseradish peroxidase (HRP)-dependent oxidation of $N$-acetyl-3,7-dihydroxyphenoxazine. The fluorescence intensity was then measured on a SpectraMax i3x Multi-Mode microplate reader (Molecular Devices, Sunnyvale, CA, USA) using an excitation wavelength in the range of 530-560 nm and a fluorescence emission detection at $590 \mathrm{~nm}$. 


\subsection{Determination of Asbestos-Induced Cytotoxicity}

Asbestos-induced cytotoxicity was determined by quantitatively measuring extracellular levels of lactate dehydrogenase (LDH) released into the cell culture medium. LDH levels were determined using a colorimetric assay (Pierce ${ }^{\mathrm{TM}}$ LDH Cytotoxicity Assay Kit, ThermoFisher Scientific, Waltham, MA, USA) according to the manufacturer's protocol. Briefly, $50 \mu \mathrm{L}$ of cell culture media was collected at $0,1,2,4,6,8,10$, and 12-h post-asbestos exposure and transferred to a 96-well plate. The cell culture medium was incubated with $50 \mu \mathrm{L}$ of reaction mixture, containing lactate, $\mathrm{NAD}^{+}$, diaphorase, and a tetrazolium salt. $\mathrm{LDH}$ conversion of lactate to pyruvate generates NADH, which is used by diaphorase to convert the tetrazolium salt to a red formazan product that was measured at $490 \mathrm{~nm}$. Data are reported as LDH cytotoxicity (absorbance 490-680 nm).

\subsection{Evaluation of Lipid Peroxidation}

Malondialdehyde (MDA), an indicator of oxidative stress (19) was measured in the cell culture medium using a commercially available kit (TBARS Assay Kit, Cayman Chemical, Ann Arbor, MI, USA) according to the manufacturer's protocol. Elicited murine peritoneal macrophages were plated in a 6-well plate $\left(2 \times 10^{6}\right.$ cells/well) and exposed to $50 \mu \mathrm{M}$ synthetic SDG (LGM2605) 4-h prior to exposure to sterile UICC crocidolite (SPI Supplies, West Chester, PA, USA) asbestos fibers $\left(20 \mu \mathrm{g} / \mathrm{cm}^{2}\right)$. The levels of MDA were determined in the cell culture medium at 0, 1, 2, 4, 6, 8, 12 and 24-h post asbestos exposure. Specifically, levels of thiobarbituric acid reactive substances (TBARS) were quantified by measuring the fluorescence of malondialdehyde-thiobarbituric acid (MDA-TBA) adducts in cell culture medium samples. According to manufacturer instructions, MDA-TBA adducts were formed via acid hydrolysis at $100^{\circ} \mathrm{C}$ and measured fluorometrically using a SpectraMax i3x Multi-Mode microplate reader (Molecular Devices, Sunnyvale, CA, USA) with an excitation wavelength of $530 \mathrm{~nm}$ and an emission wavelength of $550 \mathrm{~nm}$. Levels of lipid peroxidation in cell culture medium samples are reported as the concentration (nM) of MDA [58].

\subsection{Analysis of 8-Iso Prostaglandin F2a Levels in the Cell Culture Medium}

Levels of 8-iso Prostaglandin F2a (8-IsoP), metabolites of tissue phospholipid oxidation and a biomarker of oxidative stress and antioxidant deficiency, in cell culture medium were determined using an 8-iso Prostaglandin F2a enzyme-linked immunosorbent assay (ELISA) kit (Cayman Chemical, Ann Arbor, MI, USA) according to the manufacturer's protocol. Elicited murine peritoneal macrophages were plated in a 6-well plate $\left(2 \times 10^{6}\right.$ cells/well) and exposed to $50 \mu \mathrm{M}$ synthetic SDG (LGM2605) 4-h prior to exposure to sterile UICC crocidolite (SPI Supplies) asbestos fibers $\left(20 \mu \mathrm{g} / \mathrm{cm}^{2}\right)$. The levels of 8-IsoP were determined in the cell culture medium at $0,1,2,4,6,8,12$ and 24-h post asbestos exposure. Cell culture medium samples were run undiluted and the data are reported as the concentration (pg/mL) of 8-iso Prostaglandin F2a in the cell culture medium.

\subsection{Nrf2 Transcription Factor Analysis}

The presence of nuclear factor (erythroid-derived 2)-like 2 (Nrf2) was determined in nuclear extracts isolated from macrophages exposed to asbestos and harvested at 1, 2, 4, 6, 8, and 12-h post asbestos exposure. Cytoplasmic and nuclear extracts were prepared using a commercially available nuclear extraction kit (Cayman Chemical, Ann Arbor, MI, USA). A transcription factor assay kit (Cayman Chemical, Ann Arbor, MI, USA) was used to detect nuclear Nrf2. The assay was performed according to the manufacturer's protocol. The transcription factor assay kit utilizes a specific double-stranded DNA sequence containing the Nrf2 response element to bind to Nrf2 molecules present in the nuclear fraction. The presence of Nrf2 in the nucleus was detected by ELISA per the manufacturer's instructions. The data are reported as the ratio of the absorbance at $450 \mathrm{~nm}$ to the protein concentration of the nuclear extract $(\mu \mathrm{g})$. 


\subsection{RNA Isolation and Gene Expression Analysis}

Total RNA was isolated from murine peritoneal macrophages using a commercially available kit, RNeasy Plus Mini Kit, supplied by Qiagen (Valencia, CA, USA). Total RNA was quantified using a NanoDrop 2000 apparatus (ThermoFisher Scientific, Waltham, MA, USA). Reverse transcription of RNA to cDNA was then performed on a Veriti ${ }^{\circledR}$ Thermal Cycler using the high capacity RNA to cDNA kit supplied by Applied Biosystems Quantitative Polymerase Chain Reaction (qPCR) and performed using TaqMan ${ }^{\circledR}$ Probe-Based Gene Expression Assays supplied by Applied Biosystems, Life Technologies (Carlsbad, CA, USA). Individual TaqMan gene expression assays were selected for relevant cytoprotective and phase II antioxidant enzymes (heme oxygenase-1 (HO-1), and NADPH: quinone oxidoreductase-1 (NQO1)). Quantitative real-time PCR was performed using 50 ng of cDNA per reaction well on a StepOnePlus ${ }^{\mathrm{TM}}$ Real-Time PCR System (Applied Biosystems, Life Technologies, Carlsbad, CA, USA). Gene expression data were normalized to $\beta$-actin RNA housekeeping gene and calibrated to the control samples (CTL at time 0 ) according to the $\triangle \triangle C T$ method as previously described [49].

\subsection{Western Blot Analysis}

Immunoblot analysis of murine peritoneal macrophages at 0,8 , and 24-h post-asbestos exposure was performed as previously described [19,25] using primary antibodies against HO-1 (catalogue \# ab52947, abcam, Cambridge, MA, USA) and Nqo1 (catalogue \# NBP1-40663, Novus Biologicals, Littleton, CO, USA). Protein levels of $\mathrm{HO}-1$ and Nqo1 were detected using manufacturer recommended dilutions and quantified by densitometric analysis of specific bands (33 kDa for HO-1 and $31 \mathrm{kDa}$ for Nqo1) with $\beta$-actin normalization of protein expression using Gel-Pro Analyzer software (Version 6.0, MediaCybernetics, Silver Spring, MD, USA).

\subsection{Statistical Analysis}

All data were analyzed using two-way analysis of variance (ANOVA) to test for the main effects of time and treatment on study outcome measures. Post-tests (Tukey's multiple comparisons tests) were conducted analyzing significant differences among treatment groups (CTL, LGM2605, ASB, and ASB + LGM2605) within each time point. Statistically significant differences were determined using GraphPad Prism version 6.00 for Windows, GraphPad Software, La Jolla, CA, USA (www.graphpad.com). Results are reported as mean \pm the standard error of the mean (SEM). Levels of target gene mRNA are reported as the mean fold change from CTL at time $0 \pm$ SEM. Statistically significant differences were determined at $p$-value of 0.05 . Asterisks shown in figures indicate significant differences between asbestos-exposed (ASB) and control (CTL) exposure groups. \# shown in figures indicates significant differences between asbestos-exposed (ASB) and asbestos-exposed and LGM2605-treated (ASB + LGM2605) macrophages.

\section{Conclusions}

An ideal agent used for the chemoprevention of asbestos-induced mesothelioma must be non-toxic, tolerable, and effective in interfering in asbestos-induced carcinogenesis. LGM2605 reduced asbestos-induced ROS generation, cytotoxicity, and markers of oxidative stress in murine peritoneal macrophages and may impede the asbestos-induced oxidative signaling cascade on the way to malignancy. Importantly, the ability of LGM2605 to interfere in multiple molecular pathways (boosting antioxidant defenses and scavenging free radicals) provides strong evidence for its potential usefulness as a chemopreventive agent in asbestos-induced mesothelioma. The current study provides encouraging findings that support the further evaluation of LGM2605 in chronic, in vivo models of MM.

Acknowledgments: This work was funded in part by: NIH-R01 CA133470 (Melpo Christofidou-Solomidou), NIH- 1R21AT008291-02 (Melpo Christofidou-Solomidou), NIH-R03 CA180548 (Melpo Christofidou-Solomidou), 1P42ES023720-01 (Melpo Christofidou-Solomidou) and by pilot project support from 1P30 ES013508-02 awarded to Melpo Christofidou-Solomidou (its contents are solely the responsibility of the authors and do not necessarily represent the official views of the NIEHS, NIH). 
Author Contributions: Ralph A. Pietrofesa performed biochemical assays, conducted data analysis and interpretation, and assisted with manuscript preparation; Anastasia Velalopoulou conducted data analysis and interpretation, and contributed to writing the manuscript; Steven M. Albelda designed the study and individual experiments, assisted in data analysis and interpretation, and assisted with manuscript preparation; Melpo Christofidou-Solomidou designed the study and the individual experiments, analyzed and interpreted data, wrote the manuscript and supervised lab personnel. All co-authors reviewed the manuscript before submission and approved the final version.

Conflicts of Interest: Melpo Christofidou-Solomidou reports grants from the NIH during the conduct of the study. In addition, Melpo Christofidou-Solomidou has patents No. PCT/US14/41636 and No. PCT/US15/22501 pending and has a founders equity position in LignaMed, LLC. All other coauthors report no actual, potential, or perceived conflict of interest with regard to this manuscript.

\section{Abbreviations}

\begin{tabular}{|c|c|}
\hline 8-IsoP & 8-iso Prostaglandin F2a \\
\hline ARE & antioxidant response element \\
\hline CTL & control \\
\hline ED & enterodiol \\
\hline EL & enterolactone \\
\hline ELISA & Enzyme-linked immunosorbent assays \\
\hline FLC & Flaxseed Lignan Component \\
\hline GSTM1 & glutathione $S$-transferase mu 1 \\
\hline $\mathrm{HO}-1$ & heme oxygenase-1 \\
\hline IACUC & Institutional Animal Care and Use Committee \\
\hline IP & intraperitoneal \\
\hline KEAP1 & kelch-like ECH-associated protein 1 \\
\hline LDH & lactate dehydrogenase \\
\hline MF & macrophages \\
\hline MDA & malondialdehyde \\
\hline MDA-TBA & malondialdehyde-thiobarbituric acid \\
\hline MM & Malignant Mesothelioma \\
\hline Nrf2 & nuclear factor (erythroid-derived 2)-like 2 \\
\hline Nqo1 & NADPH: quinone oxidoreductase-1 \\
\hline PBS & phosphate-buffered saline \\
\hline PL & peritoneal lavage \\
\hline PLF & peritoneal lavage fluid \\
\hline qPCR & quantitative polymerase chain reaction \\
\hline RNS & reactive nitrogen species \\
\hline ROS & reactive oxygen species \\
\hline SDG & secoisolariciresinol diglucoside \\
\hline UICC & Union Internationale Contre le Cancer \\
\hline WBC & white blood cells \\
\hline
\end{tabular}

\section{References}

1. Sterman, D.H.; Recio, A.; Vachani, A.; Sun, J.; Cheung, L.; DeLong, P.; Amin, K.M.; Litzky, L.A.; Wilson, J.M.; Kaiser, L.R.; et al. Long-term follow-up of patients with malignant pleural mesothelioma receiving high-dose adenovirus herpes simplex thymidine kinase/ganciclovir suicide gene therapy. Clin. Cancer Res. 2005, 11, 7444-7453. [CrossRef] [PubMed]

2. Sterman, D.H.; Kaiser, L.R.; Albelda, S.M. Advances in the treatment of malignant pleural mesothelioma. Chest 1999, 116, 504-520. [CrossRef] [PubMed]

3. Benard, F.; Sterman, D.; Smith, R.J.; Kaiser, L.R.; Albelda, S.M.; Alavi, A. Prognostic value of FDG pet imaging in malignant pleural mesothelioma. J. Nucl. Med. 1999, 40, 1241-1245. [PubMed] 
4. Carbone, M.; Yang, H. Molecular pathways: Targeting mechanisms of asbestos and erionite carcinogenesis in mesothelioma. Clin. Cancer Res. 2012, 18, 598-604. [CrossRef] [PubMed]

5. Neri, M.; Ugolini, D.; Boccia, S.; Canessa, P.A.; Cesario, A.; Leoncini, G.; Mutti, L.; Bonassi, S. Chemoprevention of asbestos-linked cancers: A systematic review. Anticancer Res. 2012, 32, 1005-1013. [PubMed]

6. Sterman, D.H.; Albelda, S.M. Advances in the diagnosis, evaluation, and management of malignant pleural mesothelioma. Respirology 2005, 10, 266-283. [CrossRef] [PubMed]

7. Bielefeldt-Ohmann, H.; Fitzpatrick, D.R.; Marzo, A.L.; Jarnicki, A.G.; Himbeck, R.P.; Davis, M.R.; Manning, L.S.; Robinson, B.W. Patho- and immunobiology of malignant mesothelioma: Characterisation of tumour infiltrating leucocytes and cytokine production in a murine model. Cancer Immunol. Immunother. 1994, 39, 347-359. [CrossRef] [PubMed]

8. Moalli, P.A.; MacDonald, J.L.; Goodglick, L.A.; Kane, A.B. Acute injury and regeneration of the mesothelium in response to asbestos fibers. Am. J. Pathol. 1987, 128, 426-445. [PubMed]

9. Bielefeldt-Ohmann, H.; Jarnicki, A.G.; Fitzpatrick, D.R. Molecular pathobiology and immunology of malignant mesothelioma. J. Pathol. 1996, 178, 369-378. [CrossRef]

10. Ramos-Nino, M.E.; Testa, J.R.; Altomare, D.A.; Pass, H.I.; Carbone, M.; Bocchetta, M.; Mossman, B.T. Cellular and molecular parameters of mesothelioma. J. Cell. Biochem. 2006, 98, 723-734. [CrossRef] [PubMed]

11. Thompson, J.K.; Westbom, C.M.; MacPherson, M.B.; Mossman, B.T.; Heintz, N.H.; Spiess, P.; Shukla, A. Asbestos modulates thioredoxin-thioredoxin interacting protein interaction to regulate inflammasome activation. Part. Fibre Toxicol. 2014, 11. [CrossRef] [PubMed]

12. Dostert, C.; Petrilli, V.; Van Bruggen, R.; Steele, C.; Mossman, B.T.; Tschopp, J. Innate immune activation through NALP3 inflammasome sensing of asbestos and silica. Science 2008, 320, 674-677. [CrossRef] [PubMed]

13. Shukla, A.; Gulumian, M.; Hei, T.K.; Kamp, D.; Rahman, Q.; Mossman, B.T. Multiple roles of oxidants in the pathogenesis of asbestos-induced diseases. Free Radic. Biol. Med. 2003, 34, 1117-1129. [CrossRef]

14. Moyer, V.D.; Cistulli, C.A.; Vaslet, C.A.; Kane, A.B. Oxygen radicals and asbestos carcinogenesis. Environ. Health Perspect. 1994, 102, 131-136. [CrossRef] [PubMed]

15. Greenwald, P. Cancer chemoprevention. BMJ 2002, 324, 714-718. [CrossRef] [PubMed]

16. Robinson, B.W.; Lake, R.A. Advances in malignant mesothelioma. N. Engl. J. Med. 2005, 353, 1591-1603. [CrossRef] [PubMed]

17. Heintz, N.H.; Janssen-Heininger, Y.M.; Mossman, B.T. Asbestos, lung cancers, and mesotheliomas: From molecular approaches to targeting tumor survival pathways. Am. J. Respir. Cell Mol. Biol. 2010, 42, 133-139. [CrossRef] [PubMed]

18. Kinniry, P.; Amrani, Y.; Vachani, A.; Solomides, C.C.; Arguiri, E.; Workman, A.; Carter, J.; Christofidou-Solomidou, M. Dietary flaxseed supplementation ameliorates inflammation and oxidative tissue damage in experimental models of acute lung injury in mice. J. Nutr. 2006, 136, 1545-1551. [PubMed]

19. Lee, J.C.; Bhora, F.; Sun, J.; Cheng, G.; Arguiri, E.; Solomides, C.C.; Chatterjee, S.; Christofidou-Solomidou, M. Dietary flaxseed enhances antioxidant defenses and is protective in a mouse model of lung ischemia-reperfusion injury. Am. J. Phys. Lung Cell. Mol. Phys. 2008, 294, L255-L265. [CrossRef] [PubMed]

20. Razi, S.S.; Latif, M.J.; Li, X.; Afthinos, J.N.; Ippagunta, N.; Schwartz, G.; Sagalovich, D.; Belsley, S.J.; Connery, C.P.; Jour, G.; et al. Dietary flaxseed protects against lung ischemia reperfusion injury via inhibition of apoptosis and inflammation in a murine model. J. Surg. Res. 2011, 171, e113-e121. [CrossRef] [PubMed]

21. Lee, J.C.; Krochak, R.; Blouin, A.; Kanterakis, S.; Chatterjee, S.; Arguiri, E.; Vachani, A.; Solomides, C.C.; Cengel, K.A.; Christofidou-Solomidou, M. Dietary flaxseed prevents radiation-induced oxidative lung damage, inflammation and fibrosis in a mouse model of thoracic radiation injury. Cancer Biol. Ther. 2009, 8, 47-53. [CrossRef] [PubMed]

22. Mishra, O.P.; Simmons, N.; Tyagi, S.; Pietrofesa, R.; Shuvaev, V.V.; Valiulin, R.A.; Heretsch, P.; Nicolaou, K.C.; Christofidou-Solomidou, M. Synthesis and antioxidant evaluation of $(S, S)$ - and $(R, R)$-secoisolariciresinol diglucosides (SDGs). Bioorg. Med. Chem. Lett. 2013, 23, 5325-5328. [CrossRef] [PubMed]

23. Mishra, O.P.; Pietrofesa, R.; Christofidou-Solomidou, M. Novel synthetic $(S, S)$ and $(R, R)$-secoisolariciresinol diglucosides (SDGs) protect naked plasmid and genomic DNA from $\gamma$ radiation damage. Radiat. Res. 2014, 182, 102-110. [CrossRef] [PubMed] 
24. Pietrofesa, R.A.; Velalopoulou, A.; Arguiri, E.; Menges, C.W.; Testa, J.R.; Hwang, W.T.; Albelda, S.M.; Christofidou-Solomidou, M. Flaxseed lignans enriched in secoisolariciresinol diglucoside prevent acute asbestos-induced peritoneal inflammation in mice. Carcinogenesis 2016, 37, 177-187. [CrossRef] [PubMed]

25. Velalopoulou, A.; Tyagi, S.; Pietrofesa, R.A.; Arguiri, E.; Christofidou-Solomidou, M. The flaxseed-derived lignan phenolic secoisolariciresinol diglucoside (SDG) protects non-malignant lung cells from radiation damage. Int. J. Mol. Sci. 2015, 17. [CrossRef] [PubMed]

26. Lee, J.C.; Kinniry, P.A.; Arguiri, E.; Serota, M.; Kanterakis, S.; Chatterjee, S.; Solomides, C.C.; Javvadi, P.; Koumenis, C.; Cengel, K.A.; et al. Dietary curcumin increases antioxidant defenses in lung, ameliorates radiation-induced pulmonary fibrosis, and improves survival in mice. Radiat. Res. 2010, 173, 590-601. [CrossRef] [PubMed]

27. Tan, X.L.; Spivack, S.D. Dietary chemoprevention strategies for induction of phase ii xenobiotic-metabolizing enzymes in lung carcinogenesis: A review. Lung Cancer 2009, 65, 129-137. [CrossRef] [PubMed]

28. Kwak, M.K.; Itoh, K.; Yamamoto, M.; Kensler, T.W. Enhanced expression of the transcription factor Nrf2 by cancer chemopreventive agents: Role of antioxidant response element-like sequences in the Nrf2 promoter. Mol. Cell. Biol. 2002, 22, 2883-2892. [CrossRef] [PubMed]

29. Kwak, M.K.; Itoh, K.; Yamamoto, M.; Sutter, T.R.; Kensler, T.W. Role of transcription factor Nrf2 in the induction of hepatic phase 2 and antioxidative enzymes in vivo by the cancer chemoprotective agent, 3h-1, 2-dimethiole-3-thione. Mol. Med. 2001, 7, 135-145. [PubMed]

30. Nakamura, H.; Nishikawa, A.; Furukawa, F.; Kasahara, K.; Miyauchi, M.; Okazaki, K.; Imazawa, T.; Uchida, K.; Hirose, M. Enhancing effects of oltipraz on the development of spontaneous hepatic lesions in LEC rats. Toxicol. Pathol. 2002, 30, 173-177. [CrossRef] [PubMed]

31. Jia, Z.; Zhu, H.; Trush, M.A.; Misra, H.P.; Li, Y. Generation of superoxide from reaction of 3h-1,2-dithiole-3-thione with thiols: Implications for dithiolethione chemoprotection. Mol. Cell. Biochem. 2008, 307, 185-191. [CrossRef] [PubMed]

32. Adare, A.; Afanasiev, S.; Aidala, C.; Ajitanand, N.N.; Akiba, Y.; Al-Bataineh, H.; Alexander, J.; Al-Jamel, A.; Aoki, K.; Aphecetche, L.; et al. Suppression pattern of neutral pions at high transverse momentum in Au + Au collisions at sqrt $[\mathrm{SNN}]=200 \mathrm{GeV}$ and constraints on medium transport coefficients. Phys. Rev. Lett. 2008, 101, 232301. [CrossRef] [PubMed]

33. Kelley, M.J.; Glaser, E.M.; Herndon, J.E., 2nd; Becker, F.; Bhagat, R.; Zhang, Y.J.; Santella, R.M.; Carmella, S.G.; Hecht, S.S.; Gallot, L.; et al. Safety and efficacy of weekly oral oltipraz in chronic smokers. Cancer Epidemiol. Biomark. Prev. 2005, 14, 892-899. [CrossRef] [PubMed]

34. Hu, C.; Yuan, Y.V.; Kitts, D.D. Antioxidant activities of the flaxseed lignan secoisolariciresinol diglucoside, its aglycone secoisolariciresinol and the mammalian lignans enterodiol and enterolactone in vitro. Food Chem. Toxicol. 2007, 45, 2219-2227. [CrossRef] [PubMed]

35. Kitts, D.D.; Yuan, Y.V.; Wijewickreme, A.N.; Thompson, L.U. Antioxidant activity of the flaxseed lignan secoisolariciresinol diglycoside and its mammalian lignan metabolites enterodiol and enterolactone. Mol. Cell. Biochem. 1999, 202, 91-100. [CrossRef] [PubMed]

36. Turowski, J.B.; Pietrofesa, R.A.; Lawson, J.A.; Christofidou-Solomidou, M.; Hadjiliadis, D. Flaxseed modulates inflammatory and oxidative stress biomarkers in cystic fibrosis: A pilot study. BMC Complement. Altern. Med. 2015, 15, 148. [CrossRef] [PubMed]

37. Azrad, M.; Vollmer, R.T.; Madden, J.; Dewhirst, M.; Polascik, T.J.; Snyder, D.C.; Ruffin, M.T.; Moul, J.W.; Brenner, D.E.; Demark-Wahnefried, W. Flaxseed-derived enterolactone is inversely associated with tumor cell proliferation in men with localized prostate cancer. J. Med. Food 2013, 16, 357-360. [CrossRef] [PubMed]

38. Simbalista, R.L.; Sauerbronn, A.V.; Aldrighi, J.M.; Areas, J.A. Consumption of a flaxseed-rich food is not more effective than a placebo in alleviating the climacteric symptoms of postmenopausal women. J. Nutr. 2010, 140, 293-297. [CrossRef] [PubMed]

39. Pan, A.; Demark-Wahnefried, W.; Ye, X.; Yu, Z.; Li, H.; Qi, Q.; Sun, J.; Chen, Y.; Chen, X.; Liu, Y.; et al. Effects of a flaxseed-derived lignan supplement on C-reactive protein, IL-6 and retinol-binding protein 4 in type 2 diabetic patients. Br. J. Nutr. 2009, 101, 1145-1149. [CrossRef] [PubMed]

40. Prasad, K. Antioxidant activity of secoisolariciresinol diglucoside-derived metabolites, secoisolariciresinol, enterodiol, and enterolactone. Int. J. Angiol. 2000, 9, 220-225. [CrossRef] [PubMed]

41. Serraino, M.; Thompson, L.U. The effect of flaxseed supplementation on early risk markers for mammary carcinogenesis. Cancer Lett. 1991, 60, 135-142. [CrossRef] 
42. Serraino, M.; Thompson, L.U. The effect of flaxseed supplementation on the initiation and promotional stages of mammary tumorigenesis. Nutr. Cancer 1992, 17, 153-159. [CrossRef] [PubMed]

43. Jenab, M.; Thompson, L.U. The influence of flaxseed and lignans on colon carcinogenesis and $\beta$-glucuronidase activity. Carcinogenesis 1996, 17, 1343-1348. [CrossRef] [PubMed]

44. Yan, L.; Yee, J.A.; Li, D.; McGuire, M.H.; Thompson, L.U. Dietary flaxseed supplementation and experimental metastasis of melanoma cells in mice. Cancer Lett. 1998, 124, 181-186. [CrossRef]

45. Bergman Jungestrom, M.; Thompson, L.U.; Dabrosin, C. Flaxseed and its lignans inhibit estradiol-induced growth, angiogenesis, and secretion of vascular endothelial growth factor in human breast cancer xenografts in vivo. Clin. Cancer Res. 2007, 13, 1061-1067. [CrossRef] [PubMed]

46. Chen, J.; Saggar, J.K.; Corey, P.; Thompson, L.U. Flaxseed and pure secoisolariciresinol diglucoside, but not flaxseed hull, reduce human breast tumor growth (MCF-7) in athymic mice. J. Nutr. 2009, 139, 2061-2066. [CrossRef] [PubMed]

47. Chen, J.; Tan, K.P.; Ward, W.E.; Thompson, L.U. Exposure to flaxseed or its purified lignan during suckling inhibits chemically induced rat mammary tumorigenesis. Exp. Biol. Med. 2003, 228, 951-958.

48. Chen, J.; Thompson, L.U. Lignans and tamoxifen, alone or in combination, reduce human breast cancer cell adhesion, invasion and migration in vitro. Breast Cancer Res. Treat. 2003, 80, 163-170. [CrossRef] [PubMed]

49. Christofidou-Solomidou, M.; Tyagi, S.; Pietrofesa, R.; Dukes, F.; Arguiri, E.; Turowski, J.; Grieshaber, P.A.; Solomides, C.C.; Cengel, K.A. Radioprotective role in lung of the flaxseed lignan complex enriched in the phenolic secoisolariciresinol diglucoside (SDG). Radiat. Res. 2012, 178, 568-580. [CrossRef] [PubMed]

50. Blake, D.J.; Bolin, C.M.; Cox, D.P.; Cardozo-Pelaez, F.; Pfau, J.C. Internalization of libby amphibole asbestos and induction of oxidative stress in murine macrophages. Toxicol. Sci. 2007, 99, 277-288. [CrossRef] [PubMed]

51. Huang, S.X.; Partridge, M.A.; Ghandhi, S.A.; Davidson, M.M.; Amundson, S.A.; Hei, T.K. Mitochondriaderived reactive intermediate species mediate asbestos-induced genotoxicity and oxidative stress-responsive signaling pathways. Environ. Health Perspect. 2012, 120, 840-847. [CrossRef] [PubMed]

52. Christofidou-Solomidou, M.; Tyagi, S.; Tan, K.S.; Hagan, S.; Pietrofesa, R.; Dukes, F.; Arguiri, E.; Heitjan, D.F.; Solomides, C.C.; Cengel, K.A. Dietary flaxseed administered post thoracic radiation treatment improves survival and mitigates radiation-induced pneumonopathy in mice. BMC Cancer 2011, 11, 269. [CrossRef] [PubMed]

53. Robinson, C.; Walsh, A.; Larma, I.; O'Halloran, S.; Nowak, A.K.; Lake, R.A. Mextag mice exposed to asbestos develop cancer that faithfully replicates key features of the pathogenesis of human mesothelioma. Eur. J. Cancer 2011, 47, 151-161. [CrossRef] [PubMed]

54. Robinson, C.; Woo, S.; Walsh, A.; Nowak, A.K.; Lake, R.A. The antioxidants vitamins a and e and selenium do not reduce the incidence of asbestos-induced disease in a mouse model of mesothelioma. Nutr. Cancer 2012, 64, 315-322. [CrossRef] [PubMed]

55. Jube, S.; Rivera, Z.S.; Bianchi, M.E.; Powers, A.; Wang, E.; Pagano, I.; Pass, H.I.; Gaudino, G.; Carbone, M.; Yang, H. Cancer cell secretion of the damp protein HMGB1 supports progression in malignant mesothelioma. Cancer Res. 2012, 72, 3290-3301. [CrossRef] [PubMed]

56. Grigoriu, B.; Chahine, B.; Zerimech, F.; Gregoire, M.; Balduyck, M.; Copin, M.C.; Devos, P.; Lassalle, P.; Scherpereel, A. Serum mesothelin has a higher diagnostic utility than hyaluronic acid in malignant mesothelioma. Clin. Biochem. 2009, 42, 1046-1050. [CrossRef] [PubMed]

57. Pass, H.I.; Levin, S.M.; Harbut, M.R.; Melamed, J.; Chiriboga, L.; Donington, J.; Huflejt, M.; Carbone, M.; Chia, D.; Goodglick, L.; et al. Fibulin-3 as a blood and effusion biomarker for pleural mesothelioma. N. Engl. J. Med. 2012, 367, 1417-1427. [CrossRef] [PubMed]

58. Pietrofesa, R.; Turowski, J.; Tyagi, S.; Dukes, F.; Arguiri, E.; Busch, T.M.; Gallagher-Colombo, S.M.; Solomides, C.C.; Cengel, K.A.; Christofidou-Solomidou, M. Radiation mitigating properties of the lignan component in flaxseed. BMC Cancer 2013, 13, 179. [CrossRef] [PubMed]

(C) 2016 by the authors; licensee MDPI, Basel, Switzerland. This article is an open access article distributed under the terms and conditions of the Creative Commons by Attribution (CC-BY) license (http:/ / creativecommons.org/licenses/by/4.0/). 